\title{
Assessment and incidence of fish associated bacterial pathogens at hatcheries of Azad Kashmir, Pakistan
}

\author{
R. Kousar ${ }^{a}$, N. Shafi** (D), S. Andleeb ${ }^{b}$, N. Mazhar Alic, T. Akhtar ${ }^{a}$ and S. Khalid \\ ${ }^{a}$ Fisheries and Aquaculture Laboratory, Department of Zoology, University of Azad Jammu and Kashmir, \\ Muzaffarabad, 13100, Pakistan \\ ${ }^{\mathrm{b}}$ Microbial Biotechnology and Vermi-technology Laboratory, Department of Zoology, University of Azad Jammu and \\ Kashmir, Muzaffarabad, 13100, Pakistan

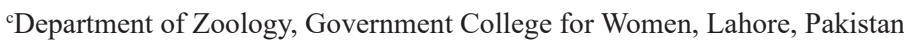 \\ *e-mail: nuzhatshfi@gmail.com
}

Received: December 7, 2018 - Accepted: March 28, 2019 - Distributed: August 31, 2020

(With 2 figures)

\begin{abstract}
Fish is the most indispensable source of proteins for individuals and have high nutritional value. On the other hand, the fish culturing raised issues of fish health due to close contact between the aquatic environment and the fish pathogens. So, the aim of the current study was to identify the bacterial pathogens and screen the injured Rainbow trout rearing in different trout hatcheries run under fisheries department of the government of Azad Jammu and Kashmir, Pakistan. Seven bacterial pathogens such as Shigella flexneri, Enterobacter amnigenus, Salmonella Typhimurium, Serratia odorifera, Pseudomonas aeruginosa, Streptococcus pyogenes, and Bacillus cereus were isolated and identified. Results revealed that the injury of fish specimens was due to overcrowding. Instead of rainbow coloration, specimens have darker black in color. The water of ponds was not clean and clear and such conditions was because of the greater quantity of feed thrown in the water. It was concluded that poor hygienic water condition and overloading allowed the opportunistic bacterial contaminations to succeed which cause a serious threat to hatcheries.
\end{abstract}

Keywords: bacterial pathogens, rainbow trout, fish hatcheries, identification of bacteria.

\section{Avaliação e incidência de patógenos bacterianos associados a peixes em incubadoras da Caxemira de Azad, Paquistão}

\section{Resumo}

O peixe é a fonte mais indispensável de proteínas para os indivíduos e tem alto valor nutricional. Por outro lado, a cultura dos peixes levantou questões sobre a saúde dos peixes devido ao próximo contato entre o ambiente aquático e os agentes patogênicos desses peixes. Assim, o objetivo do presente estudo foi identificar os patógenos bacterianos e rastrear a criação da truta arco-íris que apresentou lesões em diferentes incubadoras de trutas, com supervisão do departamento de pesca do governo de Azad Jammu e Caxemira, Paquistão. Sete patógenos bacterianos foram isolados e identificados, tais como: Shigella flexneri, Enterobacter amnigenus, Salmonella typhimurium, Serratia odorifera, Pseudomonas aeruginosa, Streptococcus pyogenes e Bacillus cereus. Os resultados revelaram que a lesão de espécimes de peixes foi devido à superlotação. Em vez da coloração do arco-íris, os espécimes tiveram uma coloração preta mais escura. A água das lagoas não era limpa e nem clara, e tais condições ocorreram devido a maior quantidade de alimento lançada na água. Concluiu-se que a precária condição higiênica da água e também a sobrecarga permitiram que as contaminações bacterianas oportunistas fossem bem-sucedidas, causando séria ameaça às incubadoras.

Palavras-chave: patógenos bacterianos, truta arco-íris, incubadoras de peixes, identificação de bactérias.

\section{Introduction}

Fish is an active, most important source of food for human beings that meet up around $60 \%$ of the world's demand for high-quality protein. Most of the emerging countries takings $30 \%$ of their yearly protein from fish (Abisoye et al., 2011). Owing to low fat and a high protein and vitamins food, fish has gained rapid attention (FAO and WHO, 2011). In many countries, freshwater fishery plays a significant role to replace the need of meat of high nutritional value (Hussain et al., 2011; Rubbani et al., 2011) and a ready source of income for smallholder farming sector (Smith and Yoshida, 2000). Globally, due to over-exploitation, fish from freshwater and marine sources are in the severe waning (Limburg et al., 2011). 
All living entities confines to tolerable parameters of water quality, any severe diminution or upswing inside these limits have adversative effects on their body functions (Kiran, 2010). Any alteration in water factors; as dissolved oxygen, temperature, transparency and $\mathrm{pH}$ add stress to the fish and affecting its production. Hence, conservation of all these factors is very crucial for obtaining maximum yield from the fish pond (Bhatnagar and Garg, 2000; Bhatnagar and Singh, 2010). Poor water quality, crowding, stress and diet issues are main subjects with fish vulnerability to parasitism. In the world fish farming and culturing has become commercially an important industry that increased many folds in the past decades. In the Punjab province of Pakistan, five species of carps comprising Hypopthalmichthys molitrix, Ctenopharygodon idella, Labeo rohita, Catla catla, Cirrhinus mrigala and Onchorynchus mykiss (rainbow trout) are successfully cultured in 7829 fish farms encompass an area of 45650 acres in private sector (Khan et al., 2011). Rainbow trout takes additional importance because of its meat quality, taste and also sport fishing (Shamspor et al., 2012).

Increased quantity of fish production can meet the protein demand of increasing human population (Sanni et al., 1999) but unfortunately, in the fish farming, sometimes parasites smash significantly their yield (Rubenfeld et al., 2005). These parasites can be virus, bacteria, fungi, and helminths, create about $45 \%$ damage in fish farms (Kabata, 2008). Diseases caused by bacteria are accountable for heavy loss in both cultured and wild fish. Some micro-organisms are primary pathogen while others are an opportunistic intruder of a host abating by some other problem (Richards and Roberts, 1978) or Stresses; prompt fish to bacterial-borne diseases (Snieszko, 1974). Similarly, rainbow trout can be a hub of different parasites like protozoans (more than 23), and metazoan (at least 169) (Lom and Dykova, 1992),

Rainbow trout have susceptible to Streptococcosis, Pseudomonas putida, Lactococcus garvieae, and Pseudomonas aeruginosa. These pathogens cause large scale commercial fatalities in fish farming (Altinok et al. 2006; Hossain et al., 2006; Austin and Austin, 2007). Increased density of farmed fish is the source of more production, but often, increased density quickens countless parasitic diseases, such diseases escort to skin and gill scratches, where opportunistic microorganisms get invasion (Eissa, 2002) and cause the maximum mortality of fish and diminish their growth rate (Abd-El-Khalek et al., 2012). Escalation of pond fish production also increases infection agents and pathological conditions (Kabata, 2008) that posed severe consequences, especially under a crowded condition.

The climate and geography of the River Neelum provide a suitable environment for the culture of cold water fish species, particularly rainbow trout (Oncorhynchus mykiss) and brown trout (Salmo trutta). Five hatcheries are working under fisheries department of GoAJ\&K on this river, but brood stocks of these hatcheries have damaged fins and tails due to overcrowding. Instead of rainbow coloration, specimens have darker black in color. The water of ponds was not clean and clear because of the greater quantity of feed thrown in the water. So, the intention of the current research was to isolate and recognize the bacterial pathogens associated with the injured and infected rainbow trout from the contaminated water rearing in different trout hatcheries of Azad Jammu and Kashmir, Pakistan.

\section{Material and Methods}

\subsection{Questionnaires regarding hatcheries data}

A questionnaire was used for the collection of information regarding the hatcheries of AJK to specify their present levels and sources of fish stocks. These questions are 1: What is the annual production of Rainbow Trout Hatchery? 2: What is its habitat? 3: What are the contents of the feed? 4: What is the diameter of a pond? 5: What is the length of the pond? 6: What is the source of hatchery water? 7: Are the ponds fully drainable? 8: How many times per day, you feed your fish? 9: What is the food of fish? 10: What is the month of breeding? 11: Which fish species do you race? 12: What is the temperature of the pond in degrees? 14: What is the condition of water? 15: What is a pond structure? 16: Do you use any chemical fertilizer? 17: How many laborers work in this hatchery? 18: What is the age of spawning of a male? 19: What is the age of spawning of female? 20: Are you a member of any organized trout group? 21: How do harvest fish outside a draining pond? 22: How do you transport fish to the river? 23: What are the causes of diseases in a hatchery? 24: Is the hatchery near city? 25: How do you manage the fish farm? 26: Which type of effluents is the hatchery receiving? 28: What is the capacity of a fish pond? 29: Do you use water filtering devices? 30: What is the estimated population of fish in a hatchery? 31: Whether the brood equipment is contaminated? 32: If yes then what type of sterilization technique do you use? 33: What is the age of the pond? 34: What kind of problems do you face? 35: Is this pond is aerated? 35: What is the size of maturity of fish? 36: What is the ratio of sex? 37: What is the number of ponds in AJK? 38: What is the pond's best production? 39: How many fish are there in one pond? 40: What is the feeding time of fish? 41: Whether the same type of food is used for fingerlings \& adults? 42: What is the duration of tank washing? 43: What is the depth of the pond? 44: What is food pattern for fry/fingerlings, and adults? 45: What is the $\mathrm{pH}$ of pond water? 46: How do you remove dead fish from a pond? 47: Where do you discard dead fish? 48: What are the signs and symptoms of diseased fish? 49: How do you analyze infected fish? 50: How do you treat infected fish? 51: Which type of medication is used by the owner? 52: Which type of infection or disease you observed in a hatchery? 53: Which types of antiseptics are used in a pond? 54: What are the techniques do you use to clean the contaminated pond?

\subsection{Sampling area}

The Department of Fisheries of Azad Jammu and Kashmir owns five small trout hatcheries in the various localities of Neelum Valley AJK, Pakistan such as Pattika, 
Salkhala, Kuttan, Dawarian, and Kail Sari. Pattika hatchery $17 \mathrm{~km}$ away from Muzaffarabad, run by professional fisheries staff trained in trout rearing, nursing, breeding, and feeding techniques. This hatchery is constructed in two separate parts, approximately $500 \mathrm{~m}$ distant, each section is supplied by the spring water source/s. Pattika breeding hatchery is regarded as an excellent trout growing center probably the reason is the availability of optimum water temperature which is $12-15^{\circ} \mathrm{C}$. Salkhala is $76 \mathrm{~km}$ away from Muzaffarabad at an altitude of $1202 \mathrm{~m}$, this is the oldest hatchery in AJK and built in 1974 but severely damaged by 1992 flood. The water source is spring water. Water temperatures range from 4 to $16{ }^{\circ} \mathrm{C}$. The hatchery is comprised of different sizes $(3 \times 0.5 \times 0.35 \mathrm{~m} ; 6.5 \times 1.5 \mathrm{~m} ; 3 \times 8 \times 1.5 \mathrm{~m})$ concrete troughs with plastic egg trays and two concrete $(3 \times 2.5 \times 1.5 \mathrm{~m})$ tanks. Kuttan unit is existing since 1982 on the Jagran stream at an elevation of $1560 \mathrm{~m}$. It is $75 \mathrm{~km}$ from Muzaffarabad. The water is frequently turbid and filtration is done through a concrete $(2 \times 2 \times 1.5 \mathrm{~m})$ de-silting tank. Temperature is ranging from $4-15{ }^{\circ} \mathrm{C}$. The hatchery contains eight $3 \times 1 \times 0.35 \mathrm{~m}$ concrete troughs with wooden egg trays. Three tanks ( 3 of $4 \times 2.5 \times 1 \mathrm{~m}$, six of $5 \times 4.5 \times 2 \mathrm{~m}$ ) are packed with fish. Ponds are in raceways form and mostly brooders are stocked here. Dawarian is situated $110 \mathrm{~km}$ north of the Muzaffarabad AJ\&K, It was established in 1985 at an elevation of $1615 \mathrm{~m}$. Temperature fluctuated between $3-12{ }^{\circ} \mathrm{C}$ seasonally. With the provision of hatchery building containing three $(3 \times 1 \times 0.35 \mathrm{~m})$ concrete troughs with wooden egg trays. 3 concrete tanks $(4 \times 2,5 \times 1 \mathrm{~m}, 6 \times 4.5 \times 2 \mathrm{~m})$ were in running position but during floods (1992 and 2010) the hatchery was completely washed away. Later in 2012 hatchery was reconstructed with the provision of hatching room and raceways. Kail Sari is also situated towards the north of the Muzaffarabad. Water supply is from an adjacent spring. Temperature ranges from $12-16^{\circ} \mathrm{C}$ in summer, $8^{\circ} \mathrm{C}$ in winter. It comprises six ponds, $(6 \times 7 \times 1.80 \times) \mathrm{m}$, in raceway form, in running with a capacity of many folds of breeding, and producing thousand $\mathrm{kg}$ trout fish. Randomly fish samples were collected from each sampling area (Figure 1).

\subsection{Chemicals, equipment, glassware}

Nutrient agar (NA; supplemented with crystal violet and methyl red), Nutrient Broth medium, MacConky agar (MA) medium, Xylose lysine deoxycholate agar (XLD) medium, and Thiosulphate citrate-bile salts sucrose agar (TCBS) medium, glycerol, and ethanol. All chemicals and reagents acquired from Merck and Sigma Aldrich (Germany), and Sigma Aldrich (Switzerland). $37^{\circ} \mathrm{C}$ incubator (MMM group Medcenter Enrich tungen $\mathrm{GmbH}$ ), $37^{\circ} \mathrm{C}$ shaker (Irmeco $\mathrm{GmbH}$, Germany), laminar flow (ESCO Prod Model; EQU/03-EHC; Serial \# 2000-0052), analytical balance (SARTORIUS GMBM GOTTINGEN, Germany), digital weighing machine (Jeweler Precision Balance Model: DH-V600A), and steam sterilizer (autoclave) were used.

\subsection{Collections of fish samples}

The rainbow trout samples (50: 10 /hatchery) were collected from all hatcheries of district Neelum, Azad Jammu and Kashmir, Pakistan. Hand net was used for capturing fish samples from ponds. After sampling, sign, and symptoms related to infected fishes were recorded. Samples were packed in polyethylene bags, labeling was done, and brought to Microbial Biotechnology laboratory, Department of Zoology, University of Azad Jammu and Kashmir, Muzaffarabad, Pakistan and stored in a refrigerator for further analysis.

\subsection{Isolation of fish pathogens}

Infected fish samples were washed with $70 \%$ absolute ethanol and later immersed into $\mathrm{d} 3 \mathrm{H} 2 \mathrm{O}$ (double distilled deionized water) for 5 minutes to take out the excess ethanol. Isolation of bacterial pathogens was carried out

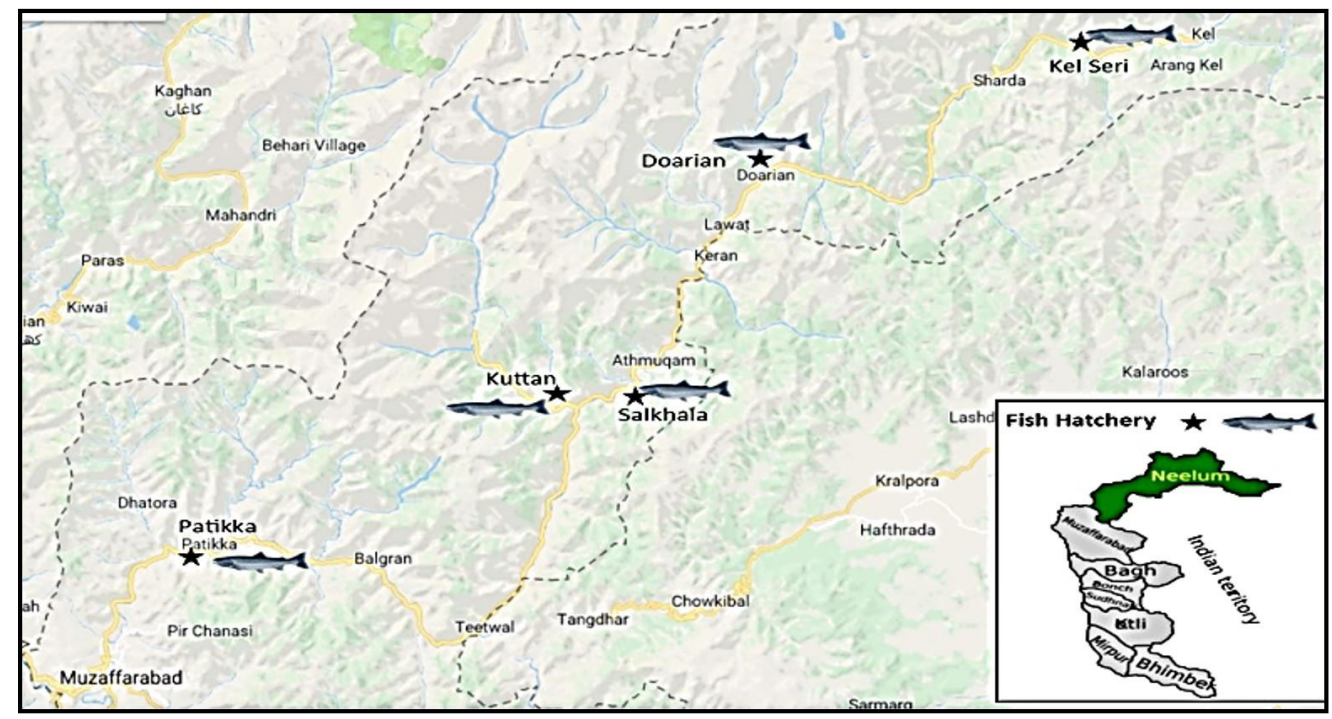

Figure 1. Map showing the study area of sample collection. 
using the protocol of Ume-Kalsoom et al. (2013) with slight modifications. Wounds on fish skin were scratched with the help of sterilized wire loop. Streaking was done with the help of wire loop on Nutrient agar (NA) medium supplemented with methyl red and crystal violet and was incubated for $24 \mathrm{~h}$ at $37^{\circ} \mathrm{C}$. After incubation, single colony was picked with the help of sterilized loop and streaked again on different media such as Nutrient agar (NA; supplemented with crystal violet and methyl red), MacConky agar (MA), Xylose lysine deoxycholate agar (XLD), and Thiosulphate citrate-bile salts sucrose agar (TCBS) respectively for the isolation of bacterial pathogen. Then, $60 \%$ glycerol stock cultures were prepared and stored at $-20^{\circ} \mathrm{C}$ for further study.

\subsection{Identification of pathogens}

After isolation, various staining techniques (Gram's Staining, Endospore staining) and biochemical tests were performed for the identification of bacterial pathogens (Collins et al., 1989; Cheesbrough, 2002).

\section{Results}

\subsection{Sign and symptoms of infected fishes}

Rainbow trout samples were collected from Pattika, Salkhalan, Kuttan, Dawarian, and Kail Sari hatcheries, respectively. Some signs and symptoms were observed such as hemorrhaging of skin and internal organs, bulging eyes, swollen abdomens, reddish tints/spots to eyes, gills, skin, and fins, and abnormal behavior, respectively (Figure 2).

\subsection{Isolation and identification of bacteria}

Various selective, enriched and differential media were used for the isolation of pure colonies of bacterial pathogens. Crystal violet and methyl red indicators were practiced for the screening of Gram-negative bacteria in comparison to Gram-positive bacteria. It was witnessed that all isolated pathogens indicated growth on types of medium used except TCBS. Seven bacteria such as Shigella flexneri, Enterobacter amnigenus, Salmonella Typhimurium, Serratia odorifera, Pseudomonas aeruginosa, Streptococcus pyogenes, and Bacillus cereus were isolated and identified (Table 1). Streptococcus and Pseudomonas spp. was found from ponds of Kuttan hatchery. Bacillus spp was recorded from ponds of Dawarian and Kail Sari. In addition to Bascillus, Kail Sari hatchery was also contaminated by the bacteria of Enterobacteriaceae family (enteric bacteria).

\subsection{Hatcheries conditions}

The study made use of data collected through questionnaire and the water quality parameters to determine water ecological status and found all raceways of five trout hatcheries supplied with neat and clean nearby spring waters; however, sometimes water channels are disturbed and adulterated with domestic animals, rain or even by villagers. It is essential that water should be hygienic and free from pollutants for trout farming. This is the most dynamic factor towards healthy farming and failing it to maintain
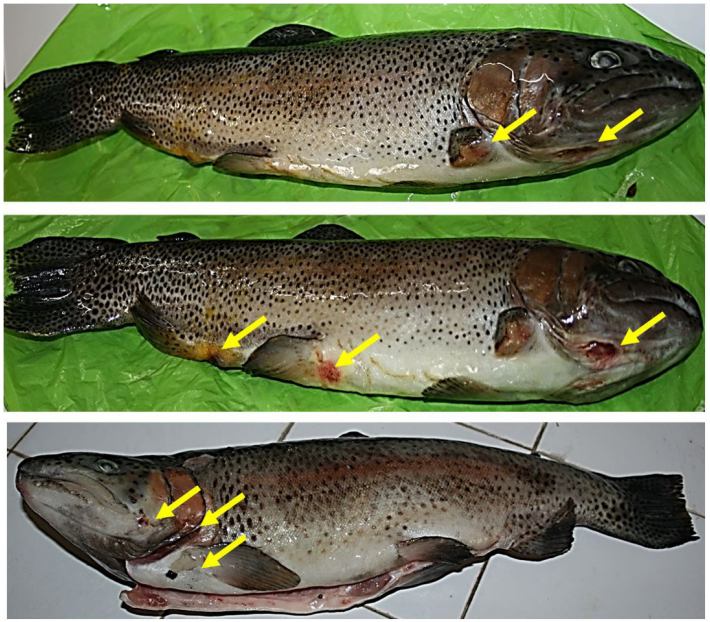

Figure 2. Sign of infected fish samples.

Table 1. Screening of Biochemical tests for the identification of fish associated bacterial pathogens.

\begin{tabular}{|c|c|c|c|c|c|c|c|}
\hline \multirow[b]{2}{*}{$\begin{array}{l}\text { Biochemical } \\
\text { techniques }\end{array}$} & \multicolumn{7}{|c|}{ Name of bacterial pathogens } \\
\hline & $\begin{array}{l}\text { Shigella } \\
\text { flexneri }\end{array}$ & $\begin{array}{c}\text { Enterobacter } \\
\text { amnigenus }\end{array}$ & $\begin{array}{c}\text { Salmonella } \\
\text { Typhimurium }\end{array}$ & $\begin{array}{c}\text { Serratia } \\
\text { odorifera }\end{array}$ & $\begin{array}{c}\text { Pseudomonas } \\
\text { aeruginosa }\end{array}$ & $\begin{array}{c}\text { Streptococcus } \\
\text { pyogenes }\end{array}$ & $\begin{array}{c}\text { Bacillus } \\
\text { cereus }\end{array}$ \\
\hline Gram staining & -VE rod & -VE rod & -VE rod & -VE rod & -VE rod & +VE Cocci & $+\mathrm{VE}$ rod \\
\hline Citrate test & $-\mathrm{VE}$ & $+\mathrm{VE}$ & $+\mathrm{VE}$ & $+\mathrm{VE}$ & $+\mathrm{VE}$ & NA & NA \\
\hline Catalase test & $+\mathrm{VE}$ & $+\mathrm{VE}$ & $+\mathrm{VE}$ & $+\mathrm{VE}$ & $-\mathrm{VE}$ & $-\mathrm{VE}$ & $+\mathrm{VE}$ \\
\hline Coagulase test & NA & NA & NA & NA & NA & $-\mathrm{VE}$ & $-\mathrm{VE}$ \\
\hline Indole test & $-\mathrm{VE}$ & $-V E$ & $-V E$ & $-V E$ & $-\mathrm{VE}$ & $-\mathrm{VE}$ & NA \\
\hline Methyl red test & $+\mathrm{VE}$ & NA & $+\mathrm{VE}$ & NA & $-\mathrm{VE}$ & NA & NA \\
\hline Oxidase test & $-\mathrm{VE}$ & $-\mathrm{VE}$ & $-\mathrm{VE}$ & $-\mathrm{VE}$ & $+\mathrm{VE}$ & $-\mathrm{VE}$ & $+\mathrm{VE}$ \\
\hline Urease test & $-\mathrm{VE}$ & $-\mathrm{VE}$ & $-\mathrm{VE}$ & $+\mathrm{VE}$ & $+\mathrm{VE}$ & $-\mathrm{VE}$ & \\
\hline Motility test & $+\mathrm{VE}$ & $+\mathrm{VE}$ & $+\mathrm{VE}$ & NA & $+\mathrm{VE}$ & $-\mathrm{VE}$ & $+\mathrm{VE}$ \\
\hline Carbohydrate test & $+\mathrm{VE}$ & $+\mathrm{VE}$ & $+\mathrm{VE}$ & $+\mathrm{VE}$ & $+\mathrm{VE}$ & $+\mathrm{VE}$ & $+\mathrm{VE}$ \\
\hline Voges proskeur test & $-\mathrm{VE}$ & $+\mathrm{VE}$ & $-\mathrm{VE}$ & $+\mathrm{VE}$ & $-\mathrm{VE}$ & $-\mathrm{VE}$ & $+\mathrm{VE}$ \\
\hline API 10 & $+\mathrm{VE}$ & $+\mathrm{VE}$ & $+\mathrm{VE}$ & $+\mathrm{VE}$ & $+\mathrm{VE}$ & $+\mathrm{VE}$ & $+\mathrm{VE}$ \\
\hline
\end{tabular}

$+\mathrm{VE}=$ Indicated; $-\mathrm{VE}=$ Not indicated; $\mathrm{NA}=$ Not applicable. 
Table 2. Descriptive Statistical water analysis of studied area during 2012-2015.

\begin{tabular}{|c|c|c|c|c|c|c|}
\hline & Temp. $\left({ }^{\circ} \mathrm{C}\right)$ & DO (mg/L) & $\mathrm{EC}(\mu \mathrm{S} / \mathrm{cm})$ & TDS (mg/L) & Turb. (NTU) & pH \\
\hline Pattika & 10.34 & 8.7 & 306.5 & 2.17 & 2.65 & 7.04 \\
\hline Salkhhalan & 9.7 & 13.07 & 314 & 0.8 & 4.5 & 6.85 \\
\hline Kuttan & 9.25 & 14.54 & 214 & 0.31 & 3.65 & 6.44 \\
\hline Dowarian & 13.2 & 15.1 & 635 & 2.01 & 4.9 & 7.11 \\
\hline Kail Seri & 13.2 & 14.45 & 69.45 & 0.6 & 3.51 & 7.91 \\
\hline Mean \pm SEM & $11.13 \pm 0.85$ & $13.17 \pm 1.166$ & $307.79 \pm 92.92$ & $1.17 \pm 0.38$ & $3.84 \pm 0.39$ & $7.07 \pm 0.24$ \\
\hline
\end{tabular}

may lead to disaster. The water chemistry should remain suitable for fish production at all time. Water temperature, dissolved oxygen, and $\mathrm{pH}$ are the main factors of water chemistry and plays a significant role in the ecology of aquatic flora and fauna (Trivedi and Goel, 1986).

It was observed that all these three parameters of all raceways of five hatcheries were in acceptable range (Table 2). Ideal water temperature fluctuates between 4 to $20^{\circ} \mathrm{C}$ (Matschak et al., 1998) and studied temperature oscillated between 9.25 to $13.2^{\circ} \mathrm{C}$. Although during studied period (2013-15) this region received less rain and snow in the winter season. Likewise, dissolved oxygen ranged from 8.7 to $15.1 \mathrm{mg} / \mathrm{L}$. It is according to water quality standard. In the same way, the measured value of $\mathrm{pH}$ reached 6.44 to 7.91 in water ponds likewise is in accordance with standard (Boyd and Tucker, 1998; Summerfelt, 2000).

Turbidity, electrical conductivity and total dissolved solids (TDS) are other three important factors for trout rearing as it required hygienic water. In different studied ponds, observed range of turbidity was between 2.65 NTU to 4.9 NTU and the values of Electrical Conductivity ranged between 69.45 to $635 \mu \mathrm{S} / \mathrm{cm}$. The rise of turbidity in some raceways was pointing an increased deposition of silt and dissolution of feed (Oryza trout feed) in water. Therefore, the presence of ions/pollution such as increased macrophytes and the nutrients in water influences the electrical conductivity (EC) of water. Fish farming is greatly affected by the EC, and it is the indication of water contamination. In the same way the mean TDS value for different ponds ranging between 0.6 to $2.17 \mathrm{mg} / \mathrm{L}$ that is an unacceptable limit for surface water proposed by the WHO. The contamination of ponds was because of the dissolved feed ingredients as well as by flooded water during monsoon from the adjacent forest. In fact, the ponds were not cleared over the year. Fisheries watchers /supervisors were not well trained in this respect. Equally, the stocking density of trout in raceways should differ in relation to water temperature and available flow; hatchery administrator did not follow this rule. Although the length and depth of cemented tank were in normal range stocking density was slightly high and male and female ratio was not appropriate as well, male brooders combat each other hence, brooder has damaged fins, skins, abdomen, reddish gills, and whitish lips and mouth. Broodstock was older (four to five years) too.

\section{Discussion}

Microorganisms are a significant portion of the aquatic ecosystem. The interaction between these pathogens and the aquatic environment blowout the contagious diseases in the process of aquaculture (Boon and Huisman, 1996; Noga, 2000; Ikpi and Offem, 2011). Fish are susceptible to bacterial infections when cultivated in high-density conditions. Our results are consistent with the previous findings (Ikpi and Offem, 2011). Disease epidemics rose up the mortality rate and decreased the productivity level causing high economic loss (Madhuri et al., 2012). It is reported that pathogens of diseased fish may be a vital probability of infection for human beings such as typhoid, fever, dysentery, cholera, and salmonellosis (Christophe et al., 2009). Aquaculture and farming is the fastest growing sector of food production worldwide. Its demand is expanding rapidly throughout the world. Recently with the increase in water pollution and intensive aquaculture development, various fish diseases as skin or gill infections or some general diseases increased in freshwater fishes that provide the basis for heavy commercial tribulations every year in aquaculture production (Inglis et al., 2001; Yang and Li, 2009). Similar results were recorded in current research.

Livestock manure which is used as fertilizer in fish ponds can raise pathogenic microbes' concentration (Musaiger and D'Souza, 2008). Thus, a bacterium causes serious trouble in both wild and stocked fish (Klindt and Town, 2005; Monette et al., 2006). The progress in fish farming has also elevated the matters of fish diseases. In Punjab, the most common fish diseases are Sapro legniasis, lernaeasis, bacterial hemorrhagic septicemia and anoxia (Iqbal et al., 2000). It has been supposed that this pathogenicity is one of the most commanding limitations on resourceful and sustainable aquaculture production, upsetting food safety, socio-economic expansion and trade (Walker, 2004). Infected fish samples were collected from Pattika, Salkhalan, Kuttan, Dawarian, and Kail Sari rainbow trout hatcheries. The isolated and identified bacterial species were: Streptococcus spp., Neisseria, Enterobacteriaceae, Bacillus spp. and Salmonella spp. Streptococcus spp. were found from ponds of Kuttan hatchery. Over a decade, Iranian aquaculturist beard more economic losses every year by Streptococcus, most prevalent infectious bacteria in cold freshwater fish farms (Akhlaghi and Keshavarzi, 2002; Darvish et al., 2009). Gram-negative bacteria were the major 
isolated bacteria and this is in agreement with outcomes described by Akinwale and Simpson (2007) in the variety of microflora survives in fish pond water. The isolation of Salmonella, Streptococcus spp, and Shigella from the fish samples specified fecal impurity of the water causing from the livestock manure that marks the entry in any way to the fish ponds. Pattika pond had more bacterial spp. It may be due to contamination, poor hygienic condition of a pond. Neisseria spp. was first time isolated from the Pattika hatchery. It damaged the reproductive organ of fish. The bacterium becomes pathogens when fish are physiologically unstable, nutritionally poor, or have other pressures, i.e., meager water quality and overstocking which permit opportunistic bacteria to succeed (Austin, 2011). In fact, Water might pose a risk to the strength of the fishes and consumers as well (Mlejnková and Sovova, 2012). Temperature affects the physiological and metabolic processes of fish along with upsetting their production (Lucinda and Martin, 1999).

During the recent study, the optimum temperature for trout production was 10 to $16^{\circ} \mathrm{C}$. Overall average temperature ranged from 8.00 to $13.00^{\circ} \mathrm{C}$, which is favorable for survival of (Salmonids) cold water fishes (Matschak et al., 1998). Temperature range also favors the survival of salmonella species. The Rainbow trout is an inhabitant of cold water at ease with 9 to $18^{\circ} \mathrm{C}$ temperature for growth in water ideal temperature is $\left(4\right.$ to $20^{\circ} \mathrm{C}$ ). Salmonella and Streptococcus spp. were able to grow at pH 3.6-9.6, during summer season increase in $\mathrm{pH}$ may cause the survival of species. The measured value of $\mathrm{pH}$ ranged from 6.44 to 7.91 in water ponds, in accordance with Boyd and Tucker (1998). Rainbow trout at these values showed better results. The factor responsible for the rise in $\mathrm{pH}$ might be the rise in temperature that subsequently increases the $\mathrm{pH}$ value that leads to came infections to fishes.

Recorded DO, TDS, Turbidity and EC was also suitable to cause infections in trout fish. Our results are consistent with findings of Solis (1988), Jamabo and Chinda (2010), and Barman et al. (2005). In this study, mean TDS value for different ponds was 2.00 to $2.23 \mathrm{mg} / \mathrm{L}$ that is an unacceptable limit for surface water proposed by the WHO. The fish production in hatcheries is strongly influenced by the TDS. It is used for aquaculture can be more than $1500 \mathrm{mg} / \mathrm{L}$ in groundwater (Summerfelt, 2000). DO is the key element which affects all aquatic organisms including fish (Solis, 1988). Eutrophication follow-on unexploited feed present in water is a probable reason for unexpected escalation in BOD (Curtis, 2001). Salinity is a foremost energetic factor that has an effect on the growth and population of the aquatic organism (Jamabo and Chinda, 2010). Fish species who reside either in fresh or saltwater habitually show poor tolerance to massive variations in water salinity (Barman et al., 2005). The greater concentration of chloride in water reflected the exceedingly higher pollution due to organic leftover of animal origin (Sahu et al., 2007). Pattika ponds likewise showed the upper range of chloride may be due to the mixing of extra feed and poor hygienic condition of these ponds. The studied physicochemical parameters revealed that the intensities found are appropriate for the farming of Oncorhynchus mykiss and therefore for aquaculture.

\section{Conclusion}

The present study concluded that water source of all hatcheries was contaminated. Different bacterial strains were isolated from a fish association. These bacteria cause a serious threat to hatchery production and hatchery personal as well. It is recommended that for the healthy and good yield from these hatcheries, the water source/ channels must be checked before entering the hatchery's ponds. Similarly, good practices, vaccination, and pest management strategies should be applied. Handlers must take due care while netting, grading, and feeding and any other activity.

\section{Acknowledgements}

Authors are highly grateful to the management of hatcheries the Department of Fisheries and Wildlife of Government of Azad Jammu and Kashmir for the provision of samples and access to hatcheries.

\section{References}

ABD-EL-KHALEK, D.E., EL-GOHARY, S.E. and EL-ZOKM, G.M., 2012. Assessment of heavy metals pollution in Oreochromis niloticus in EL-Max Fish Farm, Egypt. The Egyptian Journal of Experimental Biology (Zoology), vol. 8, no. 2, pp. 215-222.

ABISOYE, B.F., OJO, S.K.S., ADEYEMI, R.S. and OLAJUYIGBE, O.O., 2011. Bacteriological assessment of some commonly sold fishes in Lagos metropolis market Nigeria. Prime Journal of Microbiology Research, vol. 1, pp. 23-26.

AKHLAGHI, M. and KESHAVARZI, M., 2002. The occurrence of Streptococcosis in the cultured rainbow trout of Fars province. Iranian Journal of Veterinary Research, vol. 2, pp. 183-189.

AKINWALE, B. and SIMPSON, L., 2007. Quantifying stability and change in ethnic group. Journal of Official Statistics, vol. 23 , no. 2, pp. 185-208.

ALTINOK, I., KAYIS, S. and CAPKIN, E., 2006. Pseudomonas putida infection in rainbow trout. Aquaculture, vol. 261, no. 3, pp. 850-855. http://dx.doi.org/10.1016/j.aquaculture.2006.09.009.

AUSTIN, B. and AUSTIN, D.A., 2007. Bacterial fish pathogens: diseases of farmed and wild fish. UK: Praxis Publishing, $581 \mathrm{p}$.

AUSTIN, B., 2011. Taxonomy of bacterial fish pathogens. Veterinary Research (Faisalabad), vol. 42, no. 1, pp. 20. http:// dx.doi.org/10.1186/1297-9716-42-20. PMid:21314902.

BARMAN, T., FERGUSON, J.W., ALEXANDER, D.R., ALLARD, F., BODNARIK, J.G., HAUSCHILDT, P.H. and TAMANAI, A., 2005. Low temperature opacities. The Astrophysical Journal, vol. 623, no. 1, pp. 585-596.

BHATNAGAR, A. and GARG, S.K., 2000. Causative factors of fish mortality in still water fish ponds under sub-tropical conditions. Aquaculture, vol. 1, pp. 91-96.

BHATNAGAR, A. and SINGH, G., 2010. Culture fisheries in village ponds: a multi-location study in Haryana, India. Agriculture 
and Biology Journal of North America, vol. 1, no. 5, pp. 961-968. http://dx.doi.org/10.5251/abjna.2010.1.5.961.968.

BOON, J.H. and HUISMAN, E.A., 1996. Viral, bacterial and fungal diseases of Siluroidei, cultured for human consumption. Aquatic Living Resources, vol. 9, pp. 153-164.

BOYD, C.E. and TUCKER, C.S., 1998. Pond water quality management. Boston: Kluwer Academic Publishers. 700 p. http:// dx.doi.org/10.1007/978-1-4615-5407-3.

CHEESBROUGH, M., 2002. District laboratory practice in tropical countries (Part II). Great Britain: Tropical Health Technology Publishers.

CHRISTOPHE, E., VINCENT, O., GRACE, I., ETIUMA REBECCA. and JOSEPH, E., 2009. Distribution of heavy metals in bones, gills, livers and muscles of (Tilapia). Oreochromis niloticus from Henshaw Town Beach market in Calabar Nigeria. Pakistan Journal of Nutrition, vol. 8, no. 8, pp. 1209-1211. http:// dx.doi.org/10.3923/pjn.2009.1209.1211.

COLLINS, C.H., LYNE, P.M. and GRANGE, G.M., 1989. Collins and lyne microbiological methods. 6th ed. London: Butterworth.

CURTIS, G., 2001. Oregon water quality index: a tool for evaluating water quality management effectiveness. Journal of American Water Resource Association, vol. 37, no. 1, pp. 76-83. https://doi.org/10.1111/j.1752-1688.2001.tb05480.x.

DARVISH, M., YASAEI, M. and SAEEDI, A., 2009. Application of the graph theory and matrix methods to contractor ranking. International Journal of Project Management, vol. 27, no. 6, pp. 610-619. http://dx.doi.org/10.1016/j.ijproman.2008.10.004.

EISSA, I.A.M., 2002. Parasitic fish diseases in Egypt. Cairo: Dar El-Nahdda El-Arabia Publishing, pp. 52-53.

FOOD AND AGRICULTURE ORGANIZATION OF THE UNITED NATIONS - FAO and WORLD HEALTH ORGANIZATION WHO, 2011. Report of the joint FAO/WHO expert consultation on the risks and benefits of fish consumption. Rome: FAO. FAO Fisheries and Aquaculture Report, no. 978.

HOSSAIN, M.I., NEELA, F.A., HUSSAIN, M.A., RAHMAN, M.H. and SUZUKI, S., 2006. Distribution of Pseudomonas aeruginosa in swamps and its infection to Oreochromis niloticus. Journal of Biosciences, vol. 14, pp. 77-81.

HUSSAIN, S.M., JAVED, M., JAVID, A., JAVID, T. and HUSSAIN, N., 2011. Growth responses of catla catla, Labeo rohita and Cirrhina mrigala during chronic exposure of iron. Pakistan Journal of Agricultural Sciences, vol. 48, pp. 225-230.

IKPI, G. and OFFEM, B., 2011. Bacterial infection of mudfish Clarias gariepinus (Siluriformes Clariidae) fingerlings in tropical nursery ponds. Revista de Biología Tropical, vol. 59, no. 2, pp. 751-759. PMid:21717856.

INGLIS, V., ROBERTS, R.J. and BROMAGE, N.R., 2001. Bacterial diseases of fish. Ames: Iowa State University Ames, pp. 122-156.

IQBAL, Z., MINHAS, I.K. and KHAN, M.N., 2000. Disease prevalence in culturable fish species in Punjab. Pakistan. Journal of Fisheries, vol. 1, pp. 103-112.

JAMABO, N. and CHINDA, A., 2010. Aspects of the ecology of Tympanotonus fuscatus var fuscatus (Linnaeus, 1758) in the mangrove swamps of the upper Bonny River, Niger Delta, Nigeria. Current Research Journal of Biological Sciences, vol. 2, no. 1, pp. 42-47.
KABATA, Z., 2008. Parasites and diseases of fish cultured in the tropics. Taylor \& Francis, London and Philadelphia. British Journal of Pharmacology and Toxicology, vol. 2, pp. 213-226.

KHAN, A.M., ALI, Z., SHELLY, S.Y. and MIRZA, M.R., 2011. Aliens: a catastrophe for native fresh water fish diversity in Pakistan. The Journal of Animal and Plant Sciences, vol. 21, 2 suppl., pp. 435-440.

KIRAN, B.R., 2010. Physico-chemical characteristics of fish ponds of Bhadra project at Karnataka. Rasayan Journal of Chemistry, vol. 3, pp. 671-676.

KLINDT, R.M. and TOWN, B., 2005. Lake sturgeon restoration and botulism E, 2004. New York: Lake Ontario Committee Meeting, pp. 29-30. NYSDEC Lake Ontario Annual Report 2004.

LIMBURG, K.E., HUGHES, R.M., JACKSON, D.C. and BRAIN, C.Z., 2011. Human population increase, economic growth, and fish conservation collision course or savvy steward ship. Fisheries (Bethesda, Md.), vol. 36, no. 1, pp. 27-34. http:// dx.doi.org/10.1577/03632415.2011.10389053.

LOM, J. and DYKOVA, I., 1992. Protozoan parasites of fishes. USA: Elsevier Science, pp. 253-259. Developments in Aquaculture and Fisheries Science, vol. 26.

LUCINDA, C. and MARTIN, N., 1999. Oxford english mini dictionary. New York: Oxford University Press, pp. 200-535.

MADHURI, S., MANDLOI, A.K., PANDAY, G. and SAHNI, Y.P., 2012. Antimicrobial activity of some medicinal plants against fish pathogens. International Research Journal of Pharmacy, vol. 3 , no. 4 , pp. 28-30.

MATSCHAK, T.W., HHOPCROFT, T., SMASON, P., CROOK, A.R. and STICKLAND, N.C., 1998. Temperature and oxygen tension influence the development of muscle cellularity in embryonic rainbow trout. Journal of Fish Biology, vol. 53, no. 3, pp. 53-54. https://doi.org/10.1111/j.1095-8649.1998.tb01003.x.

MLEJNKOVÁ, H. and SOVOVA, K., 2012. Impact of fish pond manuring on microbial water quality. Acta Universitatis Agriculturae et Silviculturae Mendelianae Brunensis, vol. 60, no. 3, pp. 117-124.

MONETte, S., DALLAIRE, A.D., MINGELBIER, M., GROMAN, D., UHLAND, C., RICHARD, J.P., PAILLARD, G., JOHANNSON, L.M., CHIVERS, L.P., FERGUSON, H.W., LEIGHTON, F.A. and SIMKO, E., 2006. Massive mortality of common carp (Cyprinus carpio) in the St. Lawrence River in 2001: diagnostic investigation and experimental induction of lymphocytic encephalitis. Veterinary Pathology, vol. 43, no. 3, pp. 302-310. http://dx.doi.org/10.1354/vp.43-3-302. PMid:16672577.

MUSAIGER, A.O. and D'SOUZA, D.R., 2008. Chemical composition of raw fish consumed in Bahrain. Pakistan Journal of Biological Sciences, vol. 11, no. 1, pp. 55-61. http://dx.doi. org/10.3923/pjbs.2008.55.61. PMid:18819593.

NOGA, E.J., 2000. Fish disease diagnosis and treatment. Iowa, USA: Iowa State University, $321 \mathrm{pp}$.

RICHARDS, R.H. and ROBERTS, R.J., 1978. The bacteriology of teleosts. In: R. J. ROBERTS, ed. Fish pathology. London: Bailliere, Tindall, vol. 30, pp. 183-204.

RUBBANI, B.M., AFZAL, M.S., MUBARIK, M. S. and SALIM, M., 2011. Estimation of apparent digestibility coefficients of soybean meal based diets with different protein levels for Labeo rohita. Pakistan Journal of Agricultural Sciences, vol. 48, no. 3, pp. 231-235. 
RUbenfeld, G.D., CAldWell, E., PEABody, E., WEAVER, J., MARTIN, D.P., NEFF, M., STERN, E.J. and HUDSON, L.D., 2005. Incidence and outcomes of acute lung injury. The New England Journal of Medicine, vol. 353, no. 16, pp. 1685-1693. http://dx.doi.org/10.1056/NEJMoa050333. PMid:16236739.

SAHU, B., MIN, H., BANERJEE, S.K. and MACDONALD, A.H., 2007. Initio theory of gate induced gaps in graphene bilayers. Physical Review B, vol. 75, pp. 115-155.

SANNI, A.A., ONILUDE, E.O. and ADELEKE, A.I., 1999. Preparation and characteristics oflactic acid fermented cowpea milk. Zeitschriftfür Lebensmitteluntersuchung und-Forschung $A$, vol. 208, no. 3, pp. 225-229.

SHAMSPOR, S., KHARA, H. and GOLSHAHI, H., 2012. The effect of age on the fertility and natality function design guide of farming yards of warm water fishes of producer of rainbow trout: second public conference of fishery science and Iran aquatic. World Journal of Fish and Marine Sciences, vol. 5, no. 3, pp. 335-341.

SMITH, G.A. and YOSHIDA, I., 2000. Sustainable integrated Kysei nature farming EM technology and food security. Rome: FAO, vol. 3, pp. 16-25.

SNIESZKO, S.F., 1974. The effects of environmental stress on outbreaks of infectious diseases of fishes. Journal of Fish Biology, vol. 6, no. 2, pp. 197-208. http://dx.doi.org/10.1111/j.1095-8649.1974. tb04537.x.
SOLIS, N.B., 1988. The biology and culture of penaeus monodon department papers. Philippines: SEAFDEC Aquaculture Department, pp. 3-36.

SOVOVÁ, H., 2012. Steps of supercritical fluid extraction of natural products and their characteristic times. The Journal of Supercritical Fluids, vol. 66, pp. 73-79. http://dx.doi.org/10.1016/j. supflu.2011.11.004.

SUMMERFELT, R.C., 2000. Water quality considerations for aquaculture. Iowa: Iowa State University, pp. 2-7.

TRIVEDI, R.K. and GOEL, P.K., 1986. Chemical and biological methods for water pollution studies. Karad, India: Environmental Publications.

UME-KALSOOM, S., SIDDIQUE, S., SHAHZAD, N., GHOUS, T. and ANDLEEB, S., 2013. In vitro screening of herbal extracts and antibiotics against bacteria isolated from fish products at retail outlets. British Microbiology Research Journal, vol. 3, no. 1, pp. 19-31. http://dx.doi.org/10.9734/BMRJ/2013/2390.

WALKER, A., 2004. Search of our mothers' gardens: womanist prose. Boston: Houghton Mifflin Harcourt.

YANG, W. and LI, A., 2009. Isolation and characterization of Streptococcus dysgalactiae from diseased Acipenser schrenckii. Aquacult, vol. 294, no. 1-2, pp. 14-17. http://dx.doi.org/10.1016/j. aquaculture.2009.05.018. 